\title{
The Political Economy of Change
}

\section{Warren F. Ilchman and Norman Thomas Uphoff}

In this attempt to provide a social science superior to present political science and more relevant than economics for the task of analyzing public policy, especially in relation to developing countries, the authors explore the functions and characteristics of political resources, political exchange, and political productivity. This perspective permits them to compare the efficiency of various public policies and to estimate their costs. They believe that they can answer "How much is enough?" when the decision to invest in political and administrative infra-structure is made, and can incorporate the requirements of political optimality and feasibility into the same system that considers economic optimality and feasibility. For the social scientist in search of a scheme that can deal with any regime, this volume should prove stimulating and refreshing.

$$
\text { 1969 LC: } 7^{1-81743 \quad 384} \text { pages } \$ 8.50
$$

\section{from California}

University of California Press - Berkeley $947^{20}$

\section{The Australian Journal of POLITICS \& HISTORY}

Volume XV No. 2

August 1969

Andrew Inglis Clark Senior and Australian Federation J.M. Neasey

The Myth of the Unemployed: Who did vote for the Nazis?

R. I. McKibbin

The Deviations of Lord Bolingbroke

J. H. Grainger

The transport factor in developmental policy: Pioneer agricultural railways in the Western Australian wheat belt, 1900-1930 S. Glynn BOOK REVIEWS

AUSTRALIAN POLITICAL CHRONICLE

Price: $\$ 2.00$

Published three times yearly

\section{UNIVERSITY OF QUEENSLAND PRESS}


The monthly journal of the Royal Institute of International Afiairs provides the general reader with up-to-date and authoritative information on current world problems.

Recent numbers include articles on:

TRENDS IN INDUSTRIAL MANAGEMENT IN EASTERN EUROPE by Michael Kaser

FRANCE AFTER DE GAULLE by Serge Hurtig

MAO AND THE NEW MANDATE by Edgar Snow

\begin{abstract}
AUSTRALIA: CHANGING POLICIES FOR A CHANGING ENVIRONMENT by T. B. Millar
\end{abstract}

MOSCOW'S ANTI-CHINA PACT by Lawrence L. Whetten

THE POLITICS OF THE MOON by James Fawcett

Annual Subscription: 45s. (U.S.A. and Canada $\$ 6.50$ ). 4s. per issue.

Orders may be sent to booksellers and newsagents, or to the

OXFORD UNIVERSITY PRESS, Press Road, Neasden, London, N.W.10. (Tel. Dollis Hill 8080).

\title{
Social Research
}

An international quarterly of political and social science published by the Graduate Faculty of the New School. The journal emphasizes interdisciplinary treatment of issues in the social sciences and seeks to maintain the humanistic tradition by integration with the approaches of philosophy and history. Special issues are focused on problems which are examined by scholars in different fields of the social sciences.

Editorial and Business Office New School for Social Research 66 West Twelfth Street, New York 10011, N.Y.

Subscriptions $\$ 10.00$ a year, domestic and foreign. Single copies- $\$ 2.50$

SOCIAL RESEARCH is published quarterly by the Graduate Faculty of Political and Social Science of the New School for Social Research, and appears in Spring, Summer, Autumn and Winter issues. All correspondence concerning manuscripts should be addressed to Dr. Peter L. Berger. 


\section{ANNALES \\ Economies-Sociétés-Civilisations}

Revue bimestrielle, fondée en 1929 par Lucien FEBVRE et Marc BLOCH

Comité de Direction: Fernand BRAUDEL, Marc FERRO, Georges FRIEDMANN, Jacques LE GOFF, Emmanuel LE ROY LADURIE, Charles MORAZE

Secrétaire du Comité: Paul LEUILLIOT Secrétaire de la Rédaction: André BURGUIÊRE

24 e ANNEE-No. 5

FRONTIERES NOUVELLES

Maurice LEVY-LEBOYER

L'HISTOIRE SAUF L'EUROPE

Halil SAHILLIOGLU

R. W. BULLIET

INTER-SCIENCES

Marie-Louise TENEZE

LES DOMAINES DE L'HISTOIRE

SEPTEMBRE-OCTOBRE 1969

Gérard NAHON

André GUILLOU

Marcel BATAILLON

La "New Economic History".

Les années sivis et les crises monétaires de l'Empire ottoman.

Le chameau et la roue au Moyen Orient.

Introduction à l'étude de la littérature orale : le conte.

Le crédit et les Juifs dans la France du XIIIe siècle.

Aspects de la civilisation byzantine, notes sur quelques travaux récents.

Navires et gens de mer à Bordeaux aux XVe et XVIe siècles.

De la Méditerranée à l'Atlantique: Marins, produits et trafics

(H. Antoniadis-Bibicou, Dominique Chevallier, Maurice Aymand, J. M. Salmi-

Bianchi, A. J. Saraiva, Jacques Heers, Philippe Braunstein.)

ENQUÊTES EN COURS

A. GRABOIS

Simone ROUX

ART ET SOCIÉTÉ

GuY BOQUET

DEBATS ET COMBATS

M. LAMING-EMPERAIRE

André VARAGNAC
L'abbaye de Saint-Denis et les Juifs sous l'abbatiat de Suger.

L'habitat urbain au Moyen Age : le quartier de l'Université de Paris.

Eléments d'une sociologie du théâtre.

Une nouvelle approche des sociétés préhistoriques.

La succession de l'abbé Breuil : une mécanique des espèces. Une sexologie de l'art.

Rédaction: 20, rue de la Baume, Paris VIIIe (BAL 45 45)

Administration: Librarie A. COLIN, ro3 Bd Saint Michel, Paris Ve

Comptes chèques postaux: PARIS, $\mathrm{n}^{\circ} 21$ 335-25

Abonnements: France et Union Française: $35 \mathrm{~F} .:$ Etranger: $45 \mathrm{~F}$.

Le numéro de 208 p.: ${ }_{7} \mathrm{~F}$. 


\section{Estudios \\ Internacionales}

\section{REVISTA DEL INSTITUTO DE ESTUDIOS INTERNACIONALES DE LA UNIVERSIDAD DE CHILE}

\section{Director: CLAUDIO véLIZ}

Número I I*

ALAIN JOXE ¿ Fin de la Preponderancia Estratégica Norteamericana?

T. B. MnLAR Los Océanos Indico y Pacifico : Algunas Consideraciones Estratégicas.

FRANCISCO ORREGO Dilemas en el Grupo Andino.

STEPHEN HYMER Y ROBERT ROWTHORNE Las Corporaciones Multinacionales y el Oligopolio Internacional : los Americanos Desafiados.

JULIO FAÚNDEZ El Sistema Interamericano de Seguridad en la Politica Exterior de Estados Unidos.

Reseñas de Libros

Documentos

Suscripción anual: en América Latina US $\$ 10.00$ fuera de América Latina US $\$ 13.00$

Dirigirse a: Departamento de Suscripciones ESTUDIOS INTERNACIONALES

Casilla I0220

Santiago de Chile

* Para simplificar la individualización de la Revista, a contar de este número se ha adoptado la numeración correlativa en reemplazo del anterior sistema. 
Comparative Studies in Society and History is a forum for presentation and discussion of new research into problems of change and stability that recur in human societies through time or in the contemporary world. It sets up a working alliance between specialists in all branches of the social sciences and humanities. Debate and review articles bring the general reader in touch with current findings and issues.

\section{NOTES FOR CONTRIBUTORS}

Contributions may be descriptive, analytical or theoretical. Any article not in itself comparative may be accepted if it lends itself to comment that will place it in comparative perspective. Correspondence with the editors prior to the submission of articles will help to enable them to obtain such comment or a companion study. Emphasis in comparative studies may be either on similarities or, if these are significant enough and call for some recasting of generalisations, on differences. All contributions and editorial correspondence should be sent to the Editors, Comparative Studies in Society and History, Department of History, University of Michigan, Ann Arbor, Michigan 48104.

Two copies of each contribution, preferably accompanied by a stamped, addressed envelope, should be submitted. Both text and footnotes should be clearly typed with double spacing and wide margins; footnotes should appear on separate pages at the end of the article. Illustrations may be included by arrangement with the editors.

Contributors will receive 50 offprints bound in the journal covers. Any additional offprints must be ordered on receipt of the first proof. 


\section{COMPARATIVE STUDIES IN SOCIETY AND HISTORY}

\section{Communities}

Nancie L. Gonzalez The Neoteric Society

Myth and Middle Classes

Amos Perlmutter The Myth of the Myth of the New Middle Class: Some Lessons in Social and Political Theory

Manfred Hal Pern The Problem of Becoming Conscious of a Salaried New Middle Class

Emilio Willems Social Differentiation in Colonial Brazil

\section{Tradition and Change}

Leonard Kasdan and Jon H. Appleton Tradition and Change: The Case of Music

RICHARD G. Fox Avatars of Indian Research (Review Article)

\section{Medieval Society}

R. T. Lenaghan Chaucer's General Prologue as History and Literature

Dorothy C. Wertz Mankind as a Type-Figure on the Popular Religious Stage

\section{Comparative Methods}

Conrad Phillip Kottak Towards a Comparative Science of Society (Review Article) 